\section{Recent Advances of Biologically Inspired 3D Microfluidic Hydrogel Cell Culture Systems}

\author{
JM Rosser ${ }^{1}$, I Olmos Calvo ${ }^{2,3}$, M Schlager $^{2}$, M Purtscher ${ }^{4}$, F \\ Jenner ${ }^{1}$ and $P$ Ert| ${ }^{2 *}$ \\ ${ }^{1}$ University of Veterinary Medicine, Clinic for Equine Surgery, Vienna,
} Austria

${ }^{2}$ AlT Austrian Institute of Technology GmbH, Biosensor Technologies, Vienna, Austria

${ }^{3}$ Department of Medicine III, Division of Rheumatology, Medical University of Vienna, Austria

${ }^{4}$ Department of Biochemical Engineering, University of Applied Sciences Technikum Wien, Vienna, Austria

JM Rosser and I Olmos Calvo equally contributed to this manuscript as joint first authors

\section{Application of Microfluidics in Life Sciences}

Microfluidics can be defined as the study of fluid and air flows in microchannels and was initially introduced to facilitate liquid handling and sample preparations. Early work dates back to 1969 with Lew's work on a theoretical solution for mimicking blood and air flow in a microcirculatory system of the lung [1]. In this precursor stage of microfluidics the aim was to create a biomimetic system, which facilitated the study of biological pathways in vitro. It was not until the 1990s that the field of microfluidics emerged from miniaturization efforts and Micro-Electro-Mechanical Systems (MEMS) as an enabling technology platform for dispensing systems, analytical separations, chemical reactions, and bioanalysis applications. Since then, microfluidics has evolved into an established technology ranging from medical solutions (e.g., microfluidic inhalers), in vitro diagnostics (e.g., point of care) and production applications (e.g., microreaction technologies) [2]. More recent research applications include microchips for genomics, proteomics and cell-based assays.

These microfluidic cell cultures are considered potential candidates to provide next generation cell analysis systems. Starting from single cell analysis using miniaturized flow cytometers [3] a variety of microfluidic devices have been developed for cell studies to investigate cell transport and cultivation in the absence and presence of concentration and temperature gradients or shear force conditions. The main benefit of microfluidic systems for cell culture analysis is that they can perform a number of crucial liquid handling steps including cell loading, nutrient supply and waste removal under physiologically relevant shear force conditions, all while offering real time microscopy [4]. Microfluidics also enables precise regulation of soluble factors including drug candidates, growth factors at specific solution concentrations and gradients, thus providing robust and reproducible measurement conditions. An alternative application of microfluidics for cell analysis is micropatterning to (a) optimize control of cellular behavior [5], (b) allow cell migration [6], (c) spatially resolve co-cultures systems [7] and (d) define cell repulsive and adhesive areas [8].

Despite recent achievements of microfluidic 2D cell culture systems [9], they still do not address the fact that in vivo cells coexist in $3 \mathrm{D}$ communities that are influenced by spatial orientation of cells and cell-to-cell contact within the extracellular matrix [10]. It has been repeatedly demonstrated that the presence of a $3 \mathrm{D}$ matrix promotes many biologically relevant functions otherwise not observed in $2 \mathrm{D}$ monolayer cell cultures [11]. Consequently a transition from 2D to $3 \mathrm{D}$ cell cultures has gained momentum as an increasing number of reports have confirmed significant differences in the morphology, protein expression, differentiation, migration, functionality and viability of cells between $3 \mathrm{D}$ and $2 \mathrm{D}$ cell cultures [12]; these non-microfluidic advances are further discussed elsewhere [13]. It has been shown that the chemical composition of the ECM is a crucial factor regarding cell shape, differentiation and interaction [14]. For example, 3D cell culture is particularly interesting for investigation of tissue cells normally situated within a dependent, functional Extracellular Matrix (ECM), such as chondrocytes [15]. While 
cartilage ECM can be mimicked with biocompatible hydrogel, such as hyaluronic acid [16], with variable porosity and mechanical stiffness, $3 \mathrm{D}$ cultured chondrocytes also display a more native morphology and secrete ECM components. Moreover, when biodegradable scaffolds are used for 3D chondrocyte culture, native-like articular cartilage replaces the degraded hydrogel in a time dependent fashion [17].

In recent years, bioMEMS applications for hydrogels have been reviewed elsewhere [18] and a variety of microfluidic 3D cell culture platforms have been developed for recreating highly complex and well-controlled 3D microenvironments that mimic the biological niche [19]. In particular, culturing cells in hydrogels has shown to be useful in helping cells retain their native tissue-specific functions by mimicking the in vivo 3D tissue environment [20]. The combination of 3D-hydrogel cell cultures with microfluidics offers several advantages including (1) appropriate microscale dimensions that are comparable to in vivo microstructures; (2) establishment of chemical gradients to create dynamic 3D microenvironments; and (3) creation of reproducible medium-matrix biointerfaces, culminating in unprecedented temporal and spatial cellular control [21]. Fabrication of microfluidic devices [22] and microfluidics dedicated to cell culture have been reviewed previously [23]. Consequently the present review introduces recent advances and future applications of microfluidic 3D hydrogel cell cultures in the following sections.

\section{D-Hydrogels for Microfluidic Cell Culture Applications}

\section{Advantages and disadvantages of hydrogels for cell culture applications}

Hydrogels are three-dimensional networks composed of various natural and synthetic polymers that retain water by swelling up to a percentage of $90 \%$, thus mimicking the naturally surrounding of the extracellular matrix [24]. Hydrogels can be classified in two basic categories based on the origin of their composing polymer such as natural and synthetic monomers [25]. Natural or biological hydrogels used for microfluidic cell culture applications include agarose [26], chitosan [27], alginate [28], Hyaluronic Acid (HA) [29], collagen [30], dextran [31], fibrin [32], Matrigel [33], laminin [33], and silk fibroin [27]. In turn, synthetic hydrogels have been used in combination with microfluidics and are based on Poly-Ethylene Glycol (PEG) [34], Poly (Ethylene Glycol) Diacrylate (PEG-DA) [35], 2-Hydroxyethyl Methacrylate (2-HEMA) [36], Poly-2-Hydroxyethyl Methacrylate (PHEMA) [37], Poly-L-Lactic Acid (PLLA) [38], Poly-Lactic-co-Glycolic Acid (PLGA) [39], Poly-Glycerol Sebacate (PGS) [40] and PuraMatrix $^{\mathrm{TM}}$ [41], which is a fully synthetic peptide-based polymer. Among these, the most extensively employed hydrogel for microfluidic cell culture applications is PEG and compounds thereof.

Important functions of hydrogels in microfluidic devices are the establishment of cellular barriers, the encapsulation of cells and/or drugs and their distribution, as well as the production of scaffolds and wound healing matrices. Table 1 lists commonly used hydrogels for microfluidic 3D cell cultures based on the function of the matrix. This broad bandwidth of hydrogel functions is also reflected in their importance in current and future biomedical applications. The main advantage of hydrogels for microfluidic cell cultures, however, is their mimicry of extracellular matrix structures including adequate porosity for cellular organization, biocompatibility, representative stiffness and influence on cellular fate [42,43], all key parameters that promote native-like tissue function. As an example, due to their relative ease of use [44], matrix density can be readily adjusted by the degree of polymerization, which has been shown to significantly impact cell fate due to apparent diffusion restrictions and increased mechanical stiffness [45]. In another study, synthetic hydrogels were combined with biopolymers to mimic the different zones of in vivo cartilage using stem cells $[46,47]$. Moreover, the development of so-called "smart hydrogels" has allowed for time-dependent release of bioactive compounds to trigger cell responses $[48,49]$. Furthermore, hydrogel barriers have also been used to create chemical gradients [50]. A detailed review on fabrication of advanced hydrogels for ECM mimicry is covered elsewhere [51].

\begin{tabular}{|c|c|c|c|c|}
\hline Function & \multicolumn{2}{|c|}{ Hydrogel (Name / origin*) } & Composites (cells, drugs, proteins) & References \\
\hline \multicolumn{5}{|l|}{ Barrier } \\
\hline & Dextran & $\mathrm{N}$ & Breast carcinoma, endothelial cells & Zervantonakis IK et al., [52] \\
\hline \multicolumn{5}{|l|}{ Cell Delivery } \\
\hline & PEG-DA & $\mathrm{s}$ & Hepatocytes & Li CY et al., [54] \\
\hline & PEG & S & Leukemia suspension cells; cervical cancer cells & Patel et al., [55] \\
\hline & Dextran-chitosan & $\mathrm{N}$ & Fibroblasts & Oh J et al., [31] \\
\hline & PEG & S & Mouse myoblast cells; placenta-derived human mesenchymal stem cells; ESC & Allazetta S et al., [51] \\
\hline & PGS-PEG & $\mathrm{s}$ & Rabbit bone marrow derived mesenchymal stem cells & Wu Y et al., [40] \\
\hline \multicolumn{5}{|c|}{ Drug Delivery/ Screening } \\
\hline & $\mathrm{HA}$ & $\mathrm{N}$ & Bone metastatic prostatecancer cells; camptothecin; docetaxel; rapamicin & Gurski LA et al., [56] \\
\hline & Alginate & $\mathrm{N}$ & Vitamin B12 & Bal D et al., [57] \\
\hline & PHEMA & $\mathrm{s}$ & Poly(l-histidine) & Tarameshlou M et al., [58] \\
\hline & PLLA & $\mathrm{s}$ & Paclitaxel & He T et al., [38] \\
\hline & PuraMatrix TM & $\mathrm{s}$ & Breast cancer; non-small cell lung cancer; microvascular endothelial cells & Dereli-Korkut $Z$ et al., [41] \\
\hline & PEG-DA & $S$ & Hepatocytes & Li CY et al., [54] \\
\hline & PLGA & $\mathrm{s}$ & Paclitaxel; BSA; cadmium sulfide nanoparticles & Heslinga MJ et al., [39] \\
\hline & Agarose-chitosan & $\mathrm{N}$ & 5-fluorouracil & Zamora-Mora V et al., [26] \\
\hline
\end{tabular}


Citation: Rosser JM, Olmos-Calvo I, Schlager M, Purtscher M, Jenner F, et al. (2015) Recent Advances of Biologically Inspired 3D Microfluidic Hydrogel Cell Culture Systems. J Cell Biol Cell Metab 2: 005.

- Page 3 of $14 \cdot$

\begin{tabular}{|c|c|c|c|c|}
\hline \multicolumn{5}{|l|}{ Encapsulation } \\
\hline & PEG & $S$ & Leukemia suspension cells; cervical cancer cells & Patel et al., [55] \\
\hline & Alginate & $\mathrm{s}$ & Hybridoma cells; mouse breast cancer cells & Akbari S et al., [59] \\
\hline & PLLA & $N$ & Paclitaxel & He T et al., [38] \\
\hline & Dextran-chitosan & $N$ & Fibroblasts & Oh J et al., [31] \\
\hline & $\mathrm{HA}$ & $\mathrm{N}$ & Mesenchymal stem cells & Bian L et al., [29] \\
\hline & Fibrin & $\mathrm{N}$ & Chondrocytes; mesenchymal stem cells & Huipeng MA et al., [60] \\
\hline & Collagen & $\mathrm{N}$ & Skeletal muscle cells & Shimizu K et al., [30] \\
\hline & PHEMA & $s$ & Poly(I-histidine) & Johnson RP et al., [37] \\
\hline & Fibrin & $\mathrm{N}$ & Human umbilical vein endothelial cells; human lung fibroblasts & Whisler JA et al., [61] \\
\hline & PGS-PEG & $\mathrm{s}$ & Rabbit bone marrow derived mesenchymal stem cells & Wu Y et al., [40] \\
\hline & PLGA & s & Paclitaxel; BSA; cadmium sulfide nanoparticles & Heslinga MJ et al., [39] \\
\hline & Matrigel & $N$ & Adult murine pancreatic cells & Jina L et al., [33] \\
\hline \multicolumn{5}{|l|}{ Entrapment } \\
\hline & HA & $\mathrm{N}$ & Mesenchymal stem cells & Bian L et al., [29] \\
\hline & Alginate & $N$ & Breast cancer cells; doxorubicin & Yu L et al., [62] \\
\hline \multicolumn{5}{|l|}{ Implant } \\
\hline & 2-HEMA & $\mathrm{s}$ & Silicon & Schwerdt HN et al., [36] \\
\hline & PVA & $\mathrm{s}$ & & Bian L et al., [29] \\
\hline & PGS-PEG & $s$ & Rabbit bone marrow derived mesenchymal stem cells & Yu L et al., [62] \\
\hline \multicolumn{5}{|l|}{ Scaffold } \\
\hline & Fibrin & $\mathrm{N}$ & Human umbilical vein endothelial cells & Park YK et al., [32] \\
\hline & PEG & $\mathrm{s}$ & Mouse embryo fibroblasts & Guarnieri D et al., [34] \\
\hline & Fibrin-Collagen & $\mathrm{N}$ & Human umbilical vein endothelial cells & Park YK et al., [32] \\
\hline & Collagen & $\mathrm{N}$ & Human umbilical vein endothelial cells & Park YK et al., [32] \\
\hline & HA & $\mathrm{N}$ & Glioma cells; chondrogenic MSC & Lee KH et al., [63] and Toh et al., [16] \\
\hline & Chitosan-Silk & $\mathrm{N}$ & Hepatocytes & He et al., [27] \\
\hline & Laminin & $N$ & Adult murine pancreatic cells & Jina L et al., [33] \\
\hline
\end{tabular}

Table 1: Overview of frequently used hydrogels for 3D-microfluidic cell cultures.

Despite their many advantages, a number of drawbacks using hydrogels for microfluidic cell culture applications still exist and are associated with biodegradability, limited reproducibility and lack of standardization. For instance, in order to inhibit rapid degradation the addition of supplements, such as Aprotinin, throughout culture life may be required to maintain biodegradable hydrogel structures as ECM [64]. Additional technical limitations include bubble formation and inherent difficulties with introducing cell laden hydrogels in microfluidic channels prior to polymerization. Lastly, the optimum length of culture time for 3D cell populations has yet to be established for microfluidic devices [65].

\section{Relevance of Hydrogels for Microfluidic 3D Cell Culture Systems}

Since the Extracellular Matrix (ECM) is part of the natural microenvironment that influences cell organization, behavior and fate, it plays a key role for the development of advanced in vitro 3D cell-based assays [51]. For instance, substrate mechanics can also impact elements of cytoskeletal signaling; by varying mechanic properties of the applied substrate, MSC can be directed toward tendon or bone differentiation [66]. Furthermore, the interactions between stem cells and the ECM is known to generate signals relevant for cell proliferation, stimulation, differentiation and apoptosis, thus ultimately influencing tissue formation, repair and healing processes. When these communications fail, degenerative and autoimmune diseases, cancer, and diabetes can develop [67] or progress pathologically in vivo. Similarly, cell-cell interactions including signaling between same cell type and co-cultures significantly influence tissue organization, remodeling and stem cell differentiation $[68,69]$. Consequently microfluidic 3D cell culture systems have been used to study cell-matrix interactions as well as paracrine signaling in co-cultures of stem cells [70]. A recent example using a microfluidic channel network containing several interconnected chambers investigated the interaction between different cell types and diverse tissues and organ structures such as blood vessels [71]. Additionally, micropatterned cells have been used in cancer research to assess cell migration and invasive capacity of co-cultures in different hydrogels including collagen type I, Matrigel and fibrin [72]. Results of a similar study (Figure 1) showed that tissue function was significantly enhanced when hepatocytes were mixed with non-parenchymal cells in varying hydrogel layers with differing stiffness [73]. Another example of micropatterning, figure 2 displays neural cells in hydrogel for researching neuronal network formation [74]. Overall, hydrogels used in 3D cell culture settings mimic the extracellular matrix including chemo- and mechanotransduction events, thus allowing the investigation of cell-cell interaction as well as cell-matrix interactions. Although natural hydrogels are inherently biocompatible and usually biodegradable, synthetic hydrogels offer ease of use and decreased back ground noise when employing proteomic analyses and other 


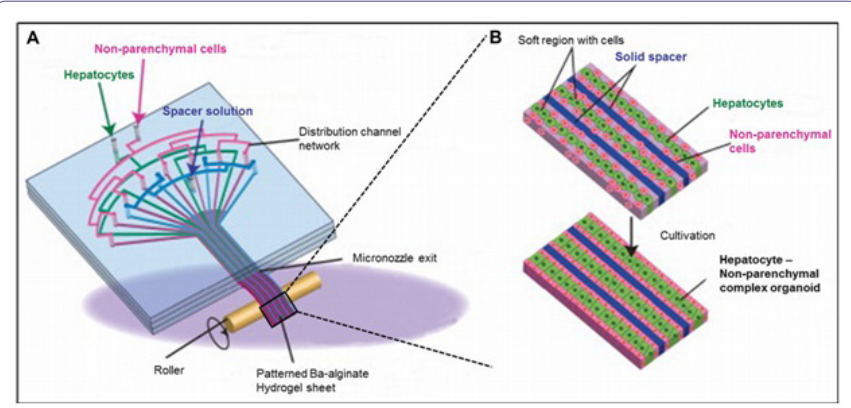

Figure 1: Schematic showing the preparation procedure of the stripe-patterned heterogeneous hydrogel sheet (A) and formation of heterotypic micro-organoids in the soft/solid hydrogel sheet (B). Reproduced with permission of Elsevier [73]

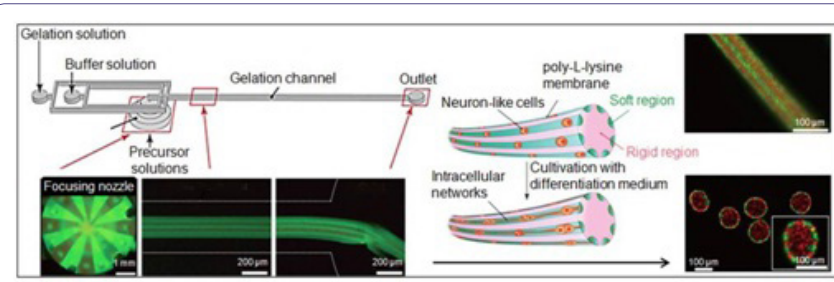

Figure 2: Patterned hydrogel microfibers in microchannels.

biologic assays [75]. These simulated ECM techniques are expected to 'bridge the gap' between monolayer cell culture and intensive animal trials [76].

Microfluidic system incorporating micronozzle array structures for producing patterned, complex hydrogel microfibers (Schematic \&fluorescence micrographs) composed of a rigid and cell-encapsulating soft regions for guiding cell proliferation and forming intercellular networks. Inset (right) shows a bundle of hydrogel microfibers. Adapted from Kitagawa Y, Naganuma Y, Yajima Y, et al., [74]. Patterned hydrogel microfibers prepared using multilayered microfluidic devices for guiding network formation of neural cells. Biofabrication, 6: 035011. http://iopscience.iop.org/17585090/6/3/035011) @ IOP Publishing. Reproduced with permission. All rights reserved.

\section{Manipulation and Sensing of Microfluidic 3D Hydrogel Cultures}

\section{D Hydrogel cell culture treatment using shear forces, stretching and patterning}

One of the main benefits of applying hydrogel for microfluidic cell cultures is the ability to establish of chemical and biological gradients in the hydrogel. For instance, the combination of different hydrogel types composed of collagen and hyaluronic acid has shown an improvement in the adhesion, migration and proliferation of Human Umbilical Vein Endothelial Cells (HUVECs) in response to a Vascular Endothelial Growth Factor (VEGF) gradient controlled by microfluidic channels during in vitro mimicking of sprouting angiogenesis [77]. As illustrated in figure 3 , microfluidics can be used to stimulate 3D hydrogel cultures thus simulating different cellular in vivo situations including shear stress, strain and stretch, compression, gravity and intracellular architecture [78]. In other words, pulsatile or constant shear force at different flow rates and biaxial or uniaxial stretching can be applied to mimic more complex biological niches. It is important to note that any changes of the ECM composition or stimulation will influence not only the interactions between cells and ECM, but also mediate cell to cell communication and signal transduction, thus guiding biological responses [79]. For instance, shear flow can provoke a direct tension force on the cellular cytoskeleton, provisioning the opening of stretch-sensitive ion channels and allowing ion flux inside the cell, thus counteracting mechanical deformations in the membrane. Laminar flow dynamic effects specific to vascular endothelial cells have been extensively reviewed elsewhere [80]. Studies in bone on a chip measured calcium dynamics at different flow rates showing that the $\mathrm{Ca}^{+2}$ response of osteoblasts was enhanced in high shear-stress conditions [81]. Also the application of shear forces (Figure 3d) have been shown to modify the morphology of endothelial cells into a more elongated shape [82], which in turn induced different cellular connections and changes in the cytoskeleton [78]. Other examples of shear force guided cell behavior involve flow directed axon guidance of neurons [82] and

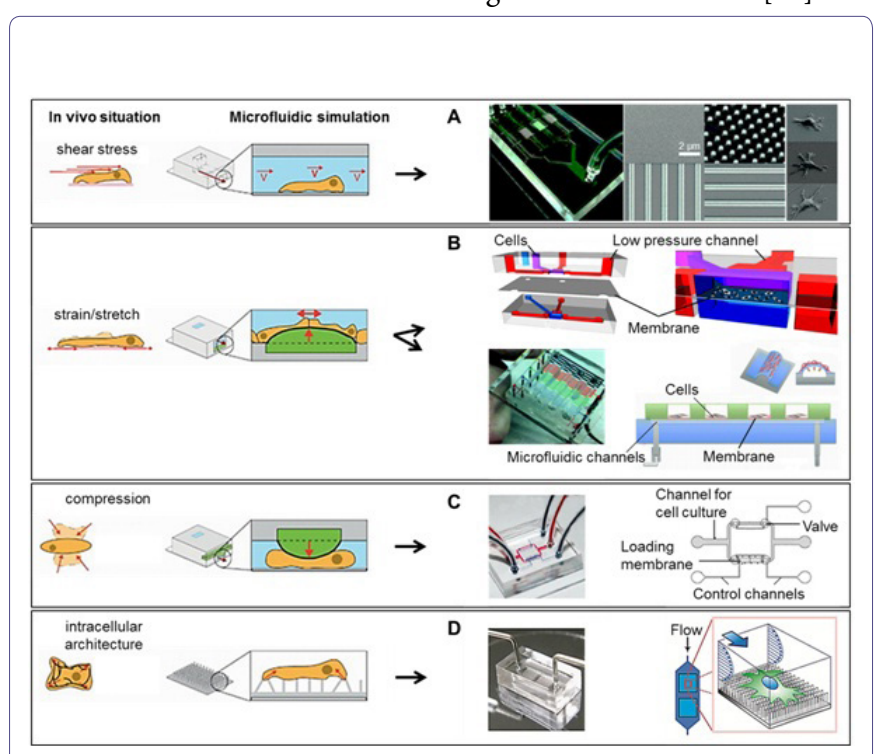

Figure 3: Stimulation strategies of microfluidic 3D cell cultures.

gene regulation $[22,84]$. Finally, a microfluidic device was developed to investigate how mechanical stress affects protein uptake by renal tubular epithelial cells [85].

Reproduced in part from: Kurth $\mathrm{F}$ et al., [78]. A new mechanobiological era: microfluidic pathways to apply and sense forces at the cellular level. Current opinion in chemical biology, 16: 400-408. Copyright (2012), with permission from Elsevier

A. Shear stress induced cell stimulation and images showing the fabricated microfluidic channel having four branch channels with patterned substrate containing a flat surface, $400 \mathrm{~nm}$ pillars, 400 $\mathrm{nm}$ perpendicular lines, and $400 \mathrm{~nm}$ parallel lines (SEM images). Reproduced in part from Ref 96 with permission of The Royal Society of Chemistry

B. Micro-scaled cell stretching devices using multi-layer PDMS-based device in combination with pneumatic actuation of a flexible membrane. Reproduced in part from Ref 161 with permission of Springer; reproduced in part from Ref 190 with permission of The Royal Society of Chemistry

C. Microfluidic device for compressive cell stimulation that mimics the mechanical strains in blood vessels. Reprinted in part from Kim 
YC, et al., [86].Microfluidic biomechanical device for compressive cell stimulation and lysis. Sensors and Actuators B: Chemical, 128: 108-116. Copyright (2007), with permission from Elsevier

D.Elastomeric microposts integrated into microfluidic for flow-mediated mechanotransduction analysis of single HUVECs plated on the PDMS micropost arrays coated with different adhesive patterns of fibronectin (left: uniform coating, right: an array of circles). The PDMS microposts were labeled with DiI (red), while HUVECs were stained for the nucleus (blue) and actin microfilaments (green). Scale bar, $50 \mu \mathrm{m}$. Reproduced in part from Lam RH, et al., [82] Elastomeric microposts integrated into microfluidics for flow-mediated endothelial mechanotransduction analysis. Lab Chip; 12: 1865-1873, with permission of The Royal Society of Chemistry

For some organs such as the heart, lungs or arteries, there is a repetition in stretching and straining movements that can also be mimicked in microfluidic devices by integrating flexible membranes [87] or by combining sold and fluid mechanical stress [88]. A prominent microfluidic device developed as a tool that can be used with any kind of cells under mechanical stimulation and optical imaging was developed by Huang [89]. A similar approach shown in figure $3 \mathrm{~b}$ studied how fibroblasts change their orientation according to the direction of the stretching [90]. In addition to stretching, compression is also an important stimulation for simulating the environment for cells forming bones and cartilage [91-94]. Also, stem cells have been found to differentiate on a chip under straining stimulation simulating the vascular system [95], as illustrated in figure $3 \mathrm{~b}$. In order to study cellular response to compression (Figure 3c), a chip that produces cellular lysis was designed to facilitate on chip cell-based analysis [86]. Compression studies in a chip with individual leukemic cells showed that extracellular calcium uptake was upregulated in stimulated cells [96]. Furthermore, mechanical compression has been used to investigate axonal degeneration after compression trauma [97] and for some diseases such as osteoarthritis [98]. Moreover, it seems that compression forces provoke shear stress of interstitial fluid in bone, thus upregulating osteogenesis [99]. Fluid dynamics, both 2D and 3D, in skeletal tissue engineering are reviewed in depth elsewhere [100].

Another cell manipulation method employed in microfluidics is micropatterning to study cell-cell and cell-matrix interactions to provide a deeper understanding in regard to bottom up tissue engineering [101]. In particular, this technique has been used for cell sorting and enrichment on-a-chip by using a diversity of nanostructures (Figure 3a) which provoked adhesion alterations between different cells [102]. Moreover, micro scale cell patterning is considered a promising field in regenerative medicine because it addresses the limitations of macro scale tissue engineering [103]. These traditional, top down engineering approaches in which cells are seeded onto bioscaffolds lack functional histostructural tissue integrity, result in suboptimal in vitro and in vivo performance. In turn, micro scale cell patterning is advantageous due to its inherent high resolution, creating cell based and cell derived tissue that mimics the native organ. Microfluidic cell patterning has been most commonly described using dielectrophoretic sorting and 3D printing; protein gradients have also been reported using microfluidic patterning [104] Hydrogel based microtissues have been used to assemble functional organoid conglomerates [105,106] and microvascular networks [107]. Despite its potential, microfluidic bottom up techniques are still susceptible to microfluidic complications, particularly those affecting long term cell culture handling including shear stresses, medium evaporation, and limited capacity for cellular growth [108].

\section{Cell-Based Biosensing Assays for Hydrogel Cultures}

In recent years, a variety of biosensing techniques based on optical, mechanical, electrical and magnetic methods have been integrated into microfluidic devices for measuring and analyzing cellular behavior [109-114]. Despites these advances, the above mentioned sensing systems are predominantly applied for $2 \mathrm{D}$ cell cultures, while microfluidic 3D hydrogel systems are still limited to optical microscopy. Consequently optical methods such as standard microscopically supported monitoring are state of the art when working with three-dimensional structures. In figure $4 \mathrm{~b}$, Nguyen et al., used classical fluorescence microscopy to monitor the sprouting and neovascularization behavior of endothelial cells from an artificial vessel into a collagen matrix [115]. Son and co-workers used time lap se fluorescence microscopy for detection of cell-secreted proteases,

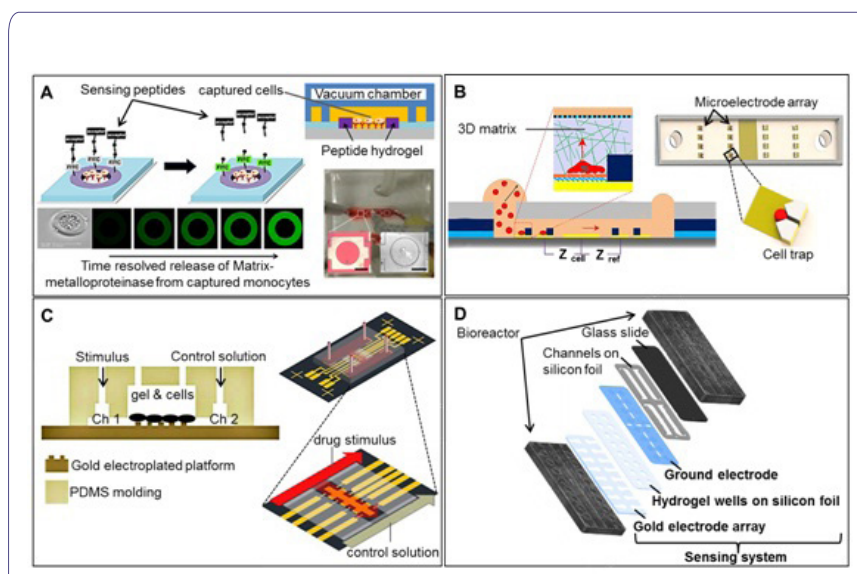

Figure 4: Sensing strategies in microfluidic 3D cell cultures.

A) Detection of MMP9protease release from Lymphoma cells bound within hydrogel rings using FRET. Protease molecules diffused into the gel and cleaved FRET peptide, resulting in fluorescence signal loss. Scale bar: $500 \mu \mathrm{m}$. Adapted with permission from Son KJ et al., [116] Micropatterned Sensing Hydrogels Integrated with Reconfigurable Microfluidcs for Detecting Protease Release from Cells. Anal Chem. 85, 11893-11901. Copyright (2013) American Chemical Society

B) Microfluidic chip with integrated electrical cell-impedance sensors for monitoring single cancer cell migration. Cross-section of the device including schematic of the sensor chip consisting of microelectrode arrays, cell capture arrays, and microfluidic channel with inlet and outlet, a V-shaped structure for single cell trapping. Reprinted in part with permission from Nguyen TA et al., [118]. Microfluidic Chip with Integrated Electrical Cell-Impedance Sensing for Monitoring Single Cancer Cell Migration in Three-Dimensional Matrixes. Anal Chem; 85, 11068-11076. Copyright 2013 American Chemical Society

C) Hydrogel-based diffusion chip containing impedance sensors for cell viability assay and drug toxicity screening. Schematic: diffusion from condition channel to control channel through the hydrogel chamber. Adapted from Tran TB [120] Hydrogel-based diffusion chip with Electrical Cell-substrate Impedance Sensing (ECIS) integration for cell viability assay and drug toxicity screening. Biosensors and Bioelectronics; 50: 453-459, Copyright (2013), with permission from Elsevier

D) Impedimetric biosensor array consisting of 16 gold electrodes to study neuronal differentiation and signaling processes. Reprinted from Valero $T$ et al., [119] Studies on neuronal differntation and signalling processes with a novel impedimetric biosensor. Biosensors and Bioelectronics; 26, 1407-1413., Copyright (2010), with permission from Elsevier 
responsible for the degradation of extra cellular matrix structures [116]. They designed a FRET (Fluorescence Resonance Energy Transfer) pair bound to a peptide, cleavable by the Metalloproteinase (MMP) 9, and incorporated them into a hydrogel-ring, as demonstrated in figure 4a. Lymphoma cells were then captured via antibodies inside of the ring and afterwards triggered for the production and release of MMP9. The released proteins diffused into the hydrogel where they activated the FRET pair and therefore gave rise to time resolved measurement using fluorescence microscopy. Alternatively, $\mathrm{Xu}$ et al., produced $50 \mathrm{nl}$ collagen droplets with a layer thickness of approximately $20-40 \mu \mathrm{m}$ containing encapsulated cells by using common printing techniques [117]. The resulting optical properties enabled the researchers to include a lens-less charge-coupled imaging system to investigate small disturbance in cell alignments caused by external stimuli.

One electroanalytical technique that has been used in 3D-hydrogel microfluidic devices is called Electrical Cell-Substrate Impedance Systems (ECIS), which detects alterations in electric properties of the cell-loaded hydrogel. For instance, Nguyen et al., developed a microfluidic chip for the investigation of single cell migration through a 3D matrix, which could be linked to further investigation on the initial steps of the invasion-metastasis cascade of cancer [118]. The described device shown in figure $4 \mathrm{~b}$ included eight double microelectrodes which were separated by a large counter electrode and placed into a microfluidic channel. The working electrodes were lined with a V-shaped capture structure for hydrodynamic single cell capture. The results of this study showed, after establishment of the chemoattractant gradient, for the MDA-MB-231 cells, a rapid variation of the impedance magnitude of about $10 \Omega / \mathrm{s}$, while within the controls no significant impedance value changes could be observed, for either the less-metastatic MCF-7 cells or the electrodes without any captured cells. Other application for the use of electrical cell-impedance sensing were shown by Valero et al., which used this technique to investigate the differentiation and signaling processes of neuronal differentiation in three dimensional matrixes (see figure $4 \mathrm{~d}$ and by Tran and co-workers, in which a cell based assay system was established for drug toxicity and anticancer drug studies $[119,120]$, as seen in figure 4c.
An alternative sensing approach involves the wide variety of physical and mechanical properties of hydrogels, which offers researchers the ability to employ temperature, $\mathrm{pH}$, and ionic strength responsive hydrogels as sensors. Furthermore, biochemical compounds such as peptides or proteins are often incorporated into hydrogels which lend even more possibilities for use as components of sensor structures. For example, in a previously published review Liu 2011 explains the integration of DNA aptamers and the subsequent increasing opportunities to use such hydrogels for on-chip analysis: smart hydrogels incorporating DNA aptamers are further described by Xiong et al., [121,122].

\section{Applications of Microfluidic 3D Cell Culture Systems}

\section{Regenerative medicine and tissue engineering applications}

In the last decade regenerative medicine has become an important part in clinical and pharmaceutical drug screening applications [123]. Table 2 summarizes the work done in this area. It is envisioned that microfluidic 3D cell culture systems may provide a deeper understanding of the parameters that influence tissue regeneration, healing and repair. The creation of a functional organ structure requires cells in culture that are provided with supportive structures, binding sites, nutrients, physical gradients and molecules, similar to those available to the specific in vivo tissue [65]. To provide such an appropriate microenvironment, different parameters such as ECM composition, 3D geometry, stiffness of the scaffold, cell density, nutrient supply, biomolecular gradient, mechanical stimuli or shear forces need to be regulated [124]. It has been shown that gradients of growth factors and other molecules, such as chemokines and cytokines that are naturally found in tissues, can be established in hydrogels [125] to achieve a more accurate microenvironment, as shown in figure 5a. While under physiological conditions, these gradients are relevant for cell migration, proliferation, homeostasis and angiogenesis [124] in pathological states these gradients also control inflammation, wound healing and cancer growth [126]. Knowledge of these processes is of prime importance for the understanding of underlying mechanisms which could perpetuate tissue dysfunction versus healing [124].

\begin{tabular}{|c|c|c|c|c|c|}
\hline Targeted Tissue & Selected Cultures & Hydrogel & Technique & Function & Reference \\
\hline Kidney & Madin Darby canine kidney cells & Geltrex/agarose & $\begin{array}{l}\text { On-demand microgel } \\
\text { formation }\end{array}$ & 3D kidney epithelialization & Eydelnant et al., [127] \\
\hline Liver & $\begin{array}{l}\text { Primary rat hepatocytes and } \\
\text { Swiss } 3 \mathrm{~T} 3 \text { cells }\end{array}$ & Alginate & Hydrogel microfiber formation & Liver specific function & Yamada et al., [128] \\
\hline Liver & $\begin{array}{l}\text { Human hepatoma and Swiss } \\
3 T 3 \text { cells }\end{array}$ & Alginate & Variable matrix stiffness & Enhanced tissue function & Kobayashi et al., [73] \\
\hline Liver & HepG2 cells & Agarose & Quantum dot cytotoxicity & $\begin{array}{l}\text { Drug diffusion from vascula- } \\
\text { ture to liver }\end{array}$ & Wu et al., [129] \\
\hline Pancreas & Mouse insulinoma 6 Beta cells & PEG & Cadherin staining & Cell aggregation & Bernard et al., [130] \\
\hline Neurite & $\begin{array}{l}\text { Dissociated cortical neurons of } \\
\text { embryonic rats }\end{array}$ & Alginate/agarose & $\begin{array}{l}\text { Differential interference } \\
\text { contrast microscopy }\end{array}$ & Neurite density & Kunze et al., [131] \\
\hline Neurite & $\begin{array}{l}\text { Dissociated cortical neurons of } \\
\text { embryonic rats }\end{array}$ & & Hyperphosphorylation & $\begin{array}{l}\text { Alzheimer-like neurodegen- } \\
\text { eration }\end{array}$ & Kunze et al., [132] \\
\hline Neurite & $\begin{array}{l}\text { Dissociated cortical neurons of } \\
\text { embryonic rats }\end{array}$ & Alginate/agarose & Multi-layer scaffolding & Physiologic cell layering & Kunze et al., [133] \\
\hline Neurite & Neuron like PC12 cells & Alginate microfibers & Tissue scaffold synthesis & Intercellular networking & Kitigawa et al., [74] \\
\hline Neurite & Neuro2a cells & $\begin{array}{l}\text { Collagen \& collagen/ } \\
\text { laminin }\end{array}$ & $\begin{array}{l}\text { Eletrical impedance spec- } \\
\text { troscopy }\end{array}$ & $\begin{array}{l}\text { Assess neural differentiation } \\
\text { in } 3 D\end{array}$ & Valero et al., [119] \\
\hline Neurite & $\begin{array}{l}\text { Embryonic rat hippocampal \& } \\
\text { DRG neurons }\end{array}$ & & Atomic force microscopy & Compressive cell stimulation & Magdesian et al., [97] \\
\hline
\end{tabular}


Citation: Rosser JM, Olmos-Calvo I, Schlager M, Purtscher M, Jenner F, et al. (2015) Recent Advances of Biologically Inspired 3D Microfluidic Hydrogel Cell Culture Systems. J Cell Biol Cell Metab 2: 005.

- Page 7 of $14 \cdot$

\begin{tabular}{|c|c|c|c|c|c|}
\hline Neurite & Mouse ESC & Gelatin & $\begin{array}{l}\text { Spatiotemporally controlled } \\
\text { neuronal commitment }\end{array}$ & $\begin{array}{l}\text { Biomolecular dose \& timing, } \\
\text { stem cell fate }\end{array}$ & Cosson et al., [108] \\
\hline Cardiovascular & $\begin{array}{l}\text { Porcine aortic valvularinterstital\& } \\
\text { endothelial cells }\end{array}$ & Gelatin-methacrylate & $\begin{array}{l}\text { Physiologic spatial arrange- } \\
\text { ment of co-culture }\end{array}$ & $\begin{array}{l}\text { Shear stress regulated para- } \\
\text { crine interactions }\end{array}$ & Chen et al., [134] \\
\hline Cardiovascular & Human mesenchymal stem cells & & Hydrodynamic actuation & Cyclic circumferential strain & Zhou et al., [95] \\
\hline Vascular & HUVECs & Type I Collagen & Physicochemical regulation & Angiogenesis analysis & Verbridge et al., [135] \\
\hline Vascular & HUVECs +/- stromal fibroblasts & $\begin{array}{l}\text { HA-dextran, agarose with } \\
\text { collagen }\end{array}$ & $\begin{array}{l}\text { Soft-lithographic and micro- } \\
\text { molding }\end{array}$ & $\begin{array}{l}\text { Structural \& biochemical } \\
\text { patterning }\end{array}$ & Jiang et al., [136] \\
\hline Vascular & Endothelial cells & Rat tail type I collagen & 3D biomimesis & Neovascularization & Nguyen et al., [115] \\
\hline \multirow[t]{2}{*}{ Vascular } & HUVECs & Degradable PEG & $\begin{array}{l}\text { Pre-vascularized PEG } \\
\text { scaffolding }\end{array}$ & $\begin{array}{l}\text { Mass transfer, angiogenic } \\
\text { quantification }\end{array}$ & Cuchiara et al., [137] \\
\hline & $\begin{array}{l}\text { HL60 (leukemic cells); Jurkat } \\
\text { lymphocytes }\end{array}$ & & $\begin{array}{l}\text { Deflectable membrane me- } \\
\text { chanical stimulation }\end{array}$ & Cell mechanosensation & Xu et al., [96] \\
\hline Skin & Epidermal and dermal cells & Type I Collagen & $3 \mathrm{D}$ cell layering & Cellular function analysis & Morimoto et al., [138] \\
\hline \multirow[t]{3}{*}{ Skin } & $\begin{array}{l}\text { Normal human dermal fibroblast } \\
\text { cells (NHDF) }\end{array}$ & & $\begin{array}{l}\text { Magneto-resistive real time } \\
\text { monitoring }\end{array}$ & $\begin{array}{l}\text { Label free detection of cellular } \\
\text { phagocytosis }\end{array}$ & Shoshi et al., [112,113] \\
\hline & Primary rat bladder SMC & Collagen & $\begin{array}{l}\text { Label free cell based bio- } \\
\text { sensing }\end{array}$ & $\begin{array}{l}\text { Morphological cellular } \\
\text { responses }\end{array}$ & Xu et al., [117] \\
\hline & U-937 lymphoma cells & PEG/PEG-DA & $\begin{array}{l}\text { FRET based signal trans- } \\
\text { duction }\end{array}$ & Protease detection & Son et al., [116] \\
\hline \multirow[t]{2}{*}{ Cancer } & $\begin{array}{l}\text { MDA-MB-231 \& MCF-7 cancer } \\
\text { cells }\end{array}$ & Matrigel & $\begin{array}{l}\text { Electric cell-substrate imped- } \\
\text { ance sensing }\end{array}$ & Cancer cell migration & Nguyen et al., [118] \\
\hline & $\begin{array}{l}\text { HeLa carcinoma \& human } \\
\text { dermal fibroblasts }\end{array}$ & & $\begin{array}{l}\text { High resolution oxygen } \\
\text { imaging }\end{array}$ & Oxygen distribution & Ungerböck et al., [114] \\
\hline Stem cells & Mesenchymal stem cells & Polyacrylamide & Traction force microscopy & Cell migration & Vincent et al., [139] \\
\hline Bone marrow & $\begin{array}{l}\text { MC3T3-E1 osteoblasts, murine } \\
\text { HSPCs }\end{array}$ & $\begin{array}{l}\text { Collagen (variable } \\
\text { densities) }\end{array}$ & Gradient hydrogel generation & Hematopoesis & Mahadik et al., [125] \\
\hline Stem cells & Human mesenchymal stem cells & PEG & 3D Co-culture & Cell signaling studies & Hamilton et al., [70] \\
\hline \multirow[t]{3}{*}{ Neurite } & Retinal ganglion axons & & Optofluidic control & Shear force cell stimulation & Gu et al., [83] \\
\hline & Human fibroblasts & & Anisotropic biaxial stretching & Cell mechanobiology & Tremblay et al., [90] \\
\hline & Mammary gland epithelial cells & & $\begin{array}{l}\text { Deformable mechanical } \\
\text { PDMS membrane }\end{array}$ & $\begin{array}{l}\text { Compressive cell stimulation } \\
\text { and lysis }\end{array}$ & Kim et al., [86] \\
\hline Cancer & $\begin{array}{l}\text { Cervical cancer cells \& mouse } \\
\text { embryonic fibroblasts }\end{array}$ & Agarose & $\begin{array}{l}\text { Electric cell-substrate imped- } \\
\text { ance sensing }\end{array}$ & $\begin{array}{l}\text { Cell viability assay, drug } \\
\text { toxicity screening }\end{array}$ & Tran et al., [120] \\
\hline Cancer & $\begin{array}{l}\text { HUVECs, NHDF, varied tumor } \\
\text { cells, T cells }\end{array}$ & & $\begin{array}{l}\text { Optical light scattering and } \\
\text { impedance sensing }\end{array}$ & Metastasis & Charwat et al., [109] \\
\hline
\end{tabular}

Table 2: Regenerative medicine and tissue engineering applications recently reported using microfluidic techniques.

A prominent example of microfluidic 3D cultures for tissue engineering applications involves on chip vascularization to study sprouting angiogenesis and progression of tube formation [140-142]. Different approaches using hydrogels have been developed to produce vascular formation on a chip. During one such study a lumen inside the microvessel was created to improve the $3 \mathrm{D}$ structure of the endothelial monolayer and medium supply using a mixture of collagen type I and Matrigel In this example, only collagen type I was used and channels were lithographically imprinted before seeding endothelial cells [135]. Another study used PDMS and prevascularized PEG hydrogel as part of the chip on which HUVEC were seeded, angiogenesis was quantified and mass transfer studied over a period of 48 and $96 \mathrm{~h}$ [137]. Gradients have also been applied to investigate sprouting angiogenesis in 3D hydrogels [141,143]. In a completely different approach, microgrooves were stamped in PDMS and Human Umbilical Vein Cells (HUVEC) and fibroblasts were co-cultured in order to study sprouting and capillary network formation [136]. More in-depth vascular specific microfluidic applications are covered elsewhere [144]. Another important vascular organ structure includes cerebral capillaries due to their special characteristics imposed by the brain. The Blood Brain Barrier
(BBB), formed specifically by astrocytes and pericytes, is composed of strongly connected endothelial cells which protect the brain from excess permeability [71]. The state of the art for $3 \mathrm{D}$ cultures mimicking BBB involves seeding of endothelial cells that are separated via a membrane from astrocytes and pericytes to study barrier function, uptake and transfer of drugs [145], however as far as we know there is not work accomplished by using microfluidics systems.

Other important on chip hydrogel-based tissue models constitute the heart, intestine, liver and kidney to elucidate possible side effects of novel drug candidates and to study tissue failure and repair. One strategy used to study tissue repair after myocardial infarct involved the injection of cells directly into fibrin [146] and PEG modified with fibrinogen hydrogels [147]. A model of heart valves has also been studied using a multilayer chip with compartmentalized cell cultures (valvular interstitial cells and valvular endothelial cells) separated by a membrane that allows cell interaction [134], illustrated in figure 5c. Microscale and microfluidic 3D models of intestinal villi have been reported to investigate oral drug absorption kinetics [148,149]. The liver on a chip is also an interesting organ model, not only to study hepatic diseases, but also as it metabolizes the vast majority of all oral 
drugs and filters toxins from circulating blood [150]. Consequently, liver tissues on a chip have been used as a drug screening model, precluding animal experimentation and human pre-clinical trials [71]. In depth, liver specific microfluidic reviews are available $[150,151]$. To study the process of diffusion from the vasculature to the liver, hepatocytes located in agarose at different distances from a channel mimicking a blood vessel were used to detect cytotoxic effects of quantum dots [129]. It was shown that microfluidic 3D culture of hepatocytes in a microdevice maintained functionally over a period of 4 weeks, while 3D structures in Matrigel, collagen type I, gelatin and alginate enhanced cell viability and slowed dedifferentiation [152]. Existing microchip devices for liver regeneration research are already commercially available from HepaChip [153], including a perfused multiwell plate $[154,155]$. Another attractive approach is the co-culture of hepatocytes with feeder cells which could be maintained for up to 3 months in alginate and showed enhanced hepatic functions such as albumin secretion and urea synthesis [128]. In a similar approach, a 5 day model for kidney epithelialization was used to test a new microdevice in which digital surface controlled the size, shape, and location of the hydrophilic sites for hydrogel adherence. Cell viability was measured during this assay designed to study medium exchange technique [127], as seen in figure 5b. In a separate study, fluid shear stress, hormone and osmotic gradients were used in a microfluidic device to study renal tubular cells [156].

Additional microfluidic hydrogel-based microsystems have been developed to study the pancreas, skin and neural activities; also, microfluidic artificial lung technology has recently been optimized to more closely resemble human gaseous exchange [157]. A technique of controlling the size of multiple wells in a microchip was designed and tested with pancreatic b-Cells. The viability of these cells when forming aggregates rose from $20 \%$ to $90 \%$, when seeded in PEG-based hydrogels that promoted cell aggregation. Results of these experiments showed that in the aggregates, cells were connecting themselves via E-cadherin junctions and they maintained their natural function of insulin secretion [130]. Skin is probably the most developed engineered tissue clinically, as skin grafts are already used in severe burn patients and to enhance wound healing. However, engineered skin can also be used on a chip to study skin related diseases as well as to test drugs and cosmetics. One innovative approach uses collagen beads with microsized skin on a chip to perform high-throughput assays. Here, keratinocytes and fibroblasts are cultured and form a compartmentalized structure which has been validated as a useful skin model [138]. Neurons, in turn, are complex cells subject to degenerative diseases and paralytic conditions; hypoxic effects on microfluidic stem cell neuronal differentiation have been reported [158]. The propagation of diseases related to tau protein was studied on a chip by seeding healthy cortical neurons in two channels separated by a network of neurites. Subsequently, Alzheimer disease was induced in one of the neurons' channels achieving both states, healthy and ill, in the same chip [132]. Since neurite density is critical for neuron viability, the number and length of neurites were investigated in 3D in a microdevice using 4 to 6 layers of hydrogel. Static and perfusion studies were also performed, showing that neurite density was significantly increased in the presence of microfluidic perfusion [131]. Finally, a microfluidic system (see figure $5 \mathrm{~d}$ ) was developed as a model in the study of neurons and neurite network formation [133].

A variety of stem cells have been used in 3D cultures inside hydrogels in microfluidic devices to study proliferation and differentiation capacities for tissue engineering applications. The most

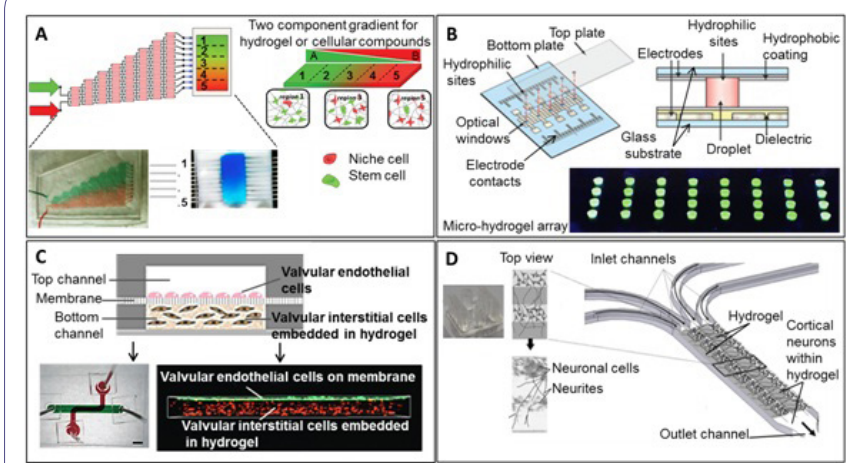

Figure 5: Devices used for regenerative medicine.

A) Microfluidic hydrogel gradient generator capable of modulating hematopoietic stem cell culture environment using two-component opposing gradient hydrogel with overlapping patterns of matrix and cell content within discrete hydrogel regions. Reproduced in part with permission from Mahadik BP et al., [125]. Microfluidic generation of gradient hydrogels to modulate hematopoietic stem cell culture environment. Advanced healthcare materials; 3: 449-458. Copyright 2014 John Wiley and Sons

B) Schematic of device: a bottom plate with patterned electrodes and a top plate bearing patterned hydrophilic sites for formation of individual microgels for reagent delivery/analysis. Reprinted by permission from Macmillan Publishers Ltd: Nature Communications; 5: 3555, Copyright 2014 (Eydelnant 2014) [127]

C) 3D microfluidic system of valvular endothelial cells separated from 3D hydrogel-laden interstitial cells via membrane. Perspective of a $3 \mathrm{D}$ confocal reconstruction demonstrating the compartmentalization and spatial arrangement of fluorescently-labelled cells in the bilayer membrane after 3 days of co-culture. Reproduced in part from Ref 20 with permission of The Royal Society of Chemistry

D) Micropatterning neural cell cultures in 3D with a multi-layered scaffold using a PDMS microdevice. 3D schematic of system: top view image demonstrates cell growth via optical microscopy. Reprinted from Kunze A et al., [133]. Micropatterning neural cell cultures in 3D with a multi-layered scaffold. Biomaterials; 32: 2088-2098, Copyright (2011), with permission from Elsevier

common cell type employed are Mesenchymal Cells (hMSCs) as they can be easily obtained from the patient and their migration potential and differentiation in the body is great. Migration studies of hMSCs in fibrin gels of different stiffness were studied mimicking different pathological states in the ECM showing that actin and microtubules are both responsible for migration [139]. Vascularization studies using hMSCs harvested from three different anatomic locations were performed in the presence of HUVEC. MSCs from the bone marrow were shown to migrate farther and to be the most supportive to HUVEC undergoing tubule formation. Moreover, cell characterization after 2 weeks of culture showed that cells were dedifferentiating into pericytes [159]. A less often used cell type is Embryonic Stem Cells (ESC), known to be extremely pluripotent. To date, human and murine ESC have been used in combination with microfluidics [160-164].

\section{Tumor Research and Anticancer Drug Delivery Research}

Cancer research is performed on many different levels, such as genomics, proteomics and therapeutic studies of candidate drugs, which are often tested in various animal models. Once more, the integration of microfluidics in this field of biological and medical research shows countless advantages, the most prominent being the replacement for animal studies and thereby lowering the immense costs, in both monetary and in animal lives [150]. In addition, 
accuracy of animal trials in predicting efficacy or toxicity in humans is unreliable, making microfluidic applications all the more promising [165]. This research is still in its infancy but promising developments have evolved over the past years, including rapid prototyped multilevel microfluidics [166]. Automation has been reported for high throughput microfluidic cancer research, and validated using an established breast carcinoma co-culture [167]. Tumors are able to create a self-protective microenvironment, which hinders the chemotherapeutic regimen from effective toxicity. By integrating cancer research in the previously described $3 \mathrm{D}$ microfluidic cell culture setups, various strategies have been tested for drug development and encapsulation thereof, in order to circumvent this critical effect. Furthermore studying the parameters of successful drug delivery to the site of the tumor is crucial for the development of new therapeutics. By integration of 3D cell cultures, mimicking the tumor environment in a microfluidic setup, perfusion, uptake and distribution of diverse drugs in the tumorous tissue can be monitored [168] and evaluated simultaneously. Albanese et al., created a 'tumor-on-a-chip' system in order to investigate nanoparticle uptake of tumor spheroids under physiological conditions. Their setup allows real-time monitoring by confocal microscopy of drug accumulation at the tumor sites. Their findings propose that the tumor-on-a-chip system provides a powerful tool for the screening of nanoparticles to reach an optimal design prior to in vivo studies [169]. Another study proposed a micro-perfusion $3 \mathrm{D}$ cell culture for chemosensitivity assays, using Epirubicin against colorectal adenocarcinoma cells. This study displayed greater resistance to cytotoxicity in 3D cancer cells compared to those cultured and treated in monolayer [170] similar findings were reported with doxorubicin in another study [171].

Especially in the long-term therapy of cancer, controlled and continuous drug administration is essential for a successful therapeutic effect. In the case of drug carriers for protein-based formulations, certain stability has to be achieved in order to avoid early drug decomposition in the organism and lower decreased cytotoxic effects. Pessi et al., developed double emulsion droplets to incorporate protein in PVA, polycaprolactone and PEG via microfluidic technology. These polymeric microcapsules showed high encapsulation efficiency (up to 84\%) of the protein and a drug release of $30 \%$ within the following $168 \mathrm{hrs}$ [172]. Also with regard to finding optimal drug concentrations, microfluidic setups have become a promising strategy. Jastrzebska et al., designed a microfluidic device in which a concentration gradient generator is incorporated to investigate the response of normal and cancer cells to the exposure of two different anti-cancer drugs [173]. Not only were they able to define the most effective drug concentration but also developed a system that generally allows the analysis of cell morphology and cytotoxicity of diverse cells and/or drugs simultaneously within very well defined parameters. A micro total bioassay system was employed to study pharmacodynamics of an oral chemotherapy agent against breast cancer, incorporating liver, duodenum, and stomach [174]. In a final chemotherapeutic example, nephrotoxicity of anticancer drugs was investigated in blood-renal barrier chip [175]. In turn, various research groups concentrate on the better understanding of cancer cell migration, metastasis and its prevention [176]. For instance, the Irimia group focuses on cell migration and developed a microfluidic device for cell migration assays, which have been successfully used for cancer cell migration studies [177]. Using advanced microfluidic systems, precise measurements of directionality and persistence during migration were studied, which are crucial parameters in the development of cancer metastasis.

\section{Future Perspectives and Current Challenges}

Despite recent advances in microfluidic 3D hydrogel cell cultures for biomedical research, some concerns remain and involve the availability of biocompatible materials and the question of whether or not microfluidic cell cultures can survive long enough to produce clinically relevant results [65]. Biochemical assays may be of limited value due to the inherent small number of cells in microdevices [178]. Another problem associated with microfluidic 3D hydrogel cultures constitutes reproducibility and device validation. Consequently, fully automated and integrated cell culture systems are needed to increase reproducibility, which is also a core request of regulatory agencies. In more sophisticated microfluidic devices, integrated microvalves and micropumps will allow the computer-controlled application of active compounds and the regulation of concentration gradients, presence of adequate shear forces and compression profiles [179]. Next generation microfluidic 3D-hydrogel cell cultures will further integrate available multilevel sensing strategies to provide high content analysis. Applicable analytics for 3D microfluidic cell cultures have yet to be exhausted and currently include both on chip and off chip analyses such as impedance biosensing [180], magnetic assays [112], immune assays, FACS, metabolomics [181,182] and proteomics via Mass Spectrometry, ELISA, fluorescence microscopy, detection of differentiation markers [183] and micro total analysis systems, previously reviewed in depth elsewhere [184]. Furthermore, pharmacologic studies of individual target tissues [185] using organ-on-a-chip technology [186] will be further supplemented by multiple organoid cell cultures [187]. In addition to toxicology screening efforts, microfluidic 3D-hydrogel models are expected to become an enabling tool for medicine to investigate various diseases such as axonal damage [179,188], alveolar epithelial injuries [189] and osteoarthritis. Finally, stem cell research is expected to benefit significantly from Lab-on-a-chip advances in automation and high throughput screening [190].

\section{Conclusion}

In an effort to recreate the in vivo microenvironment, a number of gel-supported 3D cell cultures in microfluidic devices have employed native extracellular matrix proteins as the basis of hydrogel scaffolding, such as collagen, fibrin, hyaluronic acid, Matrigel, fibronectin, agarose, poly-ethylene glycol diacrylate, and a mixture of both. Although 3D hydrogels have been shown to exhibit significant technological improvements compared to the monolayer culture, the broad practical application of such methods has not yet been achieved. Common limitations of all 3D-gel based microfluidic cell cultures include the creation of a reproducible medium-gel interface, direct medium perfusion and the inability to microstructure the 3D-hydrogel. An additional limitation of all existing microfluidic 3D cell culture systems is the lack of integrated monitoring functions to follow specific cell reactions in a non-invasive manner and over long periods of time.

\section{Acknowledgement}

The financial support by the City of Vienna (MA 23, Project 14-06) and by the Vienna Technology Fund (WWTF; LS13-092) is gratefully acknowledged. 


\section{References}

1. Lew HS, Fung YC (1969) On the low-Reynolds-number entry flow into a circular cylindrical tube. J Biomech 2: 105-119.

2. Eloy JC (2004) Status of the Mems industry. Yole Development, MIS.

3. Werner M, Merenda F, Piguet J, Salathé RP, Vogel H (2011) Microfluidic array cytometer based on refractive optical tweezers for parallel trapping, imaging and sorting of individual cells. Lab Chip 11: 2432-2439.

4. Lin L Jr, Wang SS, Wu MH, Oh-Yang CC (2011) Development of an integrated microfluidic perfusion cell culture system for real-time microscopic observation of biological cells. Sensors (Basel) 11: 8395-8411.

5. Marimuthu M, Kim S (2011) Microfluidic cell coculture methods for understanding cell biology, analyzing bio/pharmaceuticals, and developing tissue constructs. Anal Biochem 413: 81-89.

6. Javaherian S, O'Donnell KA, McGuigan AP (2011) A fast and accessible methodology for micro-patterning cells on standard culture substrates using Parafilm ${ }^{\mathrm{TM}}$ inserts. PLoS One 6: 20909.

7. Rothbauer M, Ertl P, Theiler B, Schlager M, Sleytr UB, et al. (2015) Anisotropic Crystalline Protein Nanolayers as Multifunctional Biointerfaces for $\mathrm{Si}$ multaneous Cultivation of Adherent and Non-Adherent Cells in Microfluidic Devices. Adv Mater Interfaces 2: 1400309.

8. Rothbauer M, Küpcü S, Sticker D, Sleytr UB, Ertl P (2013) Exploitation of $\mathrm{S}$-layer anisotropy: $\mathrm{pH}$-dependent nanolayer orientation for cellular micropatterning. ACS Nano 7: 8020-8030.

9. Tehranirokh M, Kouzani AZ, Francis PS, Kanwar JR (2013) Microfluidic devices for cell cultivation and proliferation. Biomicrofluidics 7: 51502.

10. Pampaloni F, Reynaud EG, Stelzer EH (2007) The third dimension bridges the gap between cell culture and live tissue. Nat Rev Mol Cell Biol 8: 839-845.

11. Chen SY, Hung PJ, Lee PJ (2011) Microfluidic array for three-dimensional perfusion culture of human mammary epithelial cells. Biomed Microdevices 13: $753-758$

12. Prot JM, Briffaut AS, Letourneur F, Chafey $P$, Merlier $F$, et al. (2011) Integrated proteomic and transcriptomic investigation of the acetaminophen toxicity in liver microfluidic biochip. PLoS One 6: 21268

13. Santos E, Hernández RM, Pedraz JL, Orive G (2012) Novel advances in the design of three-dimensional bio-scaffolds to control cell fate: translation from 2D to 3D. Trends Biotechnol 30: 331-341.

14. Peyton SR, Ghajar CM, Khatiwala CB, Putnam AJ (2007) The emergence of ECM mechanics and cytoskeletal tension as important regulators of cell function. Cell Biochem Biophys 47: 300-320.

15. Wu MH, Kuo CY (2011B) Application of high throughput perfusion micro 3-D cell culture platform for the precise study of cellular responses to extracellular conditions-effect of serum concentrations on the physiology of articular chondrocytes. Biomed.Microdevices 13: 131-141.

16. Toh WS, Lim TC, Kurisawa M, Spector M (2012) Modulation of mesenchyma stem cell chondrogenesis in a tunable hyaluronic acid hydrogel microenvironment. Biomaterials 33: 3835-3845.

17. Takahashi T, Ogasawara T, Asawa Y, Mori Y, Uchinuma E, et al. (2007) Three-dimensional microenvironments retain chondrocyte phenotypes during proliferation culture. Tissue engineering 13: 1583-1592.

18. Khaleque T, Abu-Salih S, Saunders JR, Moussa W (2011) Experimental methods of actuation, characterization and prototyping of hydrogels for bioMEMS/NEMS applications. J Nanosci Nanotechnol 11: 2470-2479.

19. Li XJ, Valadez AV, Zuo P, Nie Z (2012) Microfluidic 3D cell culture: potential application for tissue-based bioassays. Bioanalysis 4: 1509-1525.

20. El-Ali J, Sorger PK, Jensen KF (2006) Cells on chips. Nature 442: 403-411.

21. Kobel S, Lutolf MP (2011) Biomaterials meet microfluidics: building the next generation of artificial niches. Curr Opin Biotechnol 22: 690-697.
22. Castillo-León J, Svendsen WE (2015) Lab-on-a-chip devices and micro-total analysis systems: A Practical Guide. Springer, USA.

23. Meyvantsson I, Beebe DJ (2008) Cell culture models in microfluidic systems. Annu Rev Anal Chem (Palo Alto Calif) 1: 423-449.

24. Burdick JA, Murphy WL (2012) Moving from static to dynamic complexity in hydrogel design. Nat Commun 3: 1269.

25. Cushing MC, Anseth KS (2007) Materials science. Hydrogel cell cultures. Science 316: 1133-1134.

26. Zamora-Mora V, Velasco D, Hernández R, Mijangos C, Kumacheva E (2014) Chitosan/agarose hydrogels: Cooperative properties and microfluidic preparation. Carbohydrate Polymers 111: 348-355.

27. He J, Mao M, Liu Y, Zhu L, Li D (2013) Bottom-up fabrication of 3D cell-laden microfluidic constructs. Materials Letters 90: 93-96.

28. Meli L, Barbosa HS, Hickey AM, Gasimli L, Nierode G, et al. (2014) Three dimensional cellular microarray platform for human neural stem cell differentiation and toxicology. Stem Cell Res 13: 36-47.

29. Bian L, Hou C, Tous E, Rai R, Mauck RL, et al. (2013) The influence of hyaluronic acid hydrogel crosslinking density and macromolecular diffusivity on human MSC chondrogenesis and hypertrophy. Biomaterials 34: 413-421.

30. Shimizu K, Araki H, Sakata K, Tonomura W, Hashida M, et al. (2015) Microfluidic devices for construction of contractile skeletal muscle microtissues. J Biosci Bioeng 119: 212-216.

31. Oh J, Kim K, Choi S, Jung J (2014) Diffusion-assisted spherical microge fabrication using in situ gelable chitosan and dextran. Digest Journal of Nanomaterials and Biostructures 9: 739-744.

32. Park YK, Tu TY, Lim SH, Clement IJ, Yang SY, et al. (2014) In vitro microvessel growth and remodeling within a three-dimensional microfluidic environment. Cellular and Molecular Bioengineering 7: 15-25.

33. Jin L, Feng T, Shih HP, Zerda R, Luo A, et al. (2013) Colony-forming cells in the adult mouse pancreas are expandable in Matrigel and form endocrine/ acinar colonies in laminin hydrogel. Proc Natl Acad Sci USA 110: 3907-3912.

34. Guarnieri D, De Capua A, Ventre M, Borzacchiello A, Pedone C, et al. (2010) Covalently immobilized RGD gradient on PEG hydrogel scaffold influences cell migration parameters. Acta Biomater 6: 2532-2539.

35. Sivashankar S, Puttaswamy SV, Lin LH, Dai TS, Yeh CT, et al. (2013). Culturing of transgenic mice liver tissue slices in three-dimensional microfluidic structures of PEG-DA (Poly(Ethylene Glycol) Diacrylate). Sensors and Actuators B Chemical 176: 1081-1089.

36. Schwerdt HN, Bristol RE, Junseok Chae (2014) Miniaturized passive hydrogel check valve for hydrocephalus treatment. IEEE Trans Biomed Eng 61: 814-820.

37. Johnson RP, Choi E, Lee KM, Yu SJ, Chang HC, et al. (2013) Microfluid ics assisted fabrication of microspheres by poly(2-hydroxyethyl methacrylate)-block-poly(L-histidine) hybrid materials and their utilization as potential drug encapsulants. Microfluidics and Nanofluidics 14: 257-263.

38. He T, Liang Q, Zhang K, Mu X, Luo T, et al. (2011) A modified microfluidic chip for fabrication of paclitaxel-loaded poly(l-lactic acid) microspheres. Microfluidics and Nanofluidics 10: 1289-1298.

39. Heslinga MJ, Willis GM, Sobczynski DJ, Thompson AJ, Eniola-Adefeso O (2014) One-step fabrication of agent-loaded biodegradable microspheroids for drug delivery and imaging applications. Colloids Surf B Biointerfaces 116: $55-62$

40. Wu Y, Wang L, Guo B, Ma PX (2014) Injectable biodegradable hydrogels and microgels based on methacrylatedpoly(ethylene glycol)-co-poly(glycerol sebacate) multi-block copolymers: synthesis, characterization, and cell encapsulation. J Mater Chem B 2: 3674-3685

41. Dereli-Korkut Z, Akaydin HD, Ahmed AH, Jiang X, Wang S (2014) Three dimensional microfluidic cell arrays for ex vivo drug screening with mimicked vascular flow. Anal Chem 86: 2997-3004 
42. Gobaa S, Hoehnel S, Roccio M, Negro A, Kobel S, et al. (2011) Artificial niche microarrays for probing single stem cell fate in high throughput. Nat Methods 8: 949-955.

43. Tse JR, Engler AJ (2011) Stiffness gradients mimicking in vivo tissue variation regulate mesenchymal stem cell fate. See comment in PubMed Commons below PLoS One 6: 15978.

44. Lee JH, Gu Y, Wang H, Lee WY (2012) Microfluidic 3D bone tissue model fo high-throughput evaluation of wound-healing and infection-preventing biomaterials. Biomaterials 33: 999-1006.

45. Shamloo A, Xu H, Heilshorn S (2012) Mechanisms of vascular endothelial growth factor-induced pathfinding by endothelial sprouts in biomaterials. Tissue Eng Part A 18: 320-330.

46. Nguyen LH, Kudva AK, Saxena NS, Roy K (2011) Engineering articular cartilage with spatially varying matrix composition and mechanical properties from a single stem cell population using a multi-layered hydrogel. Biomaterials 32 : 6946-6952.

47. Nguyen LH, Kudva AK, Guckert NL, Linse KD, Roy K (2011) Unique biomaterial compositions direct bone marrow stem cells into specific chondrocytic phenotypes corresponding to the various zones of articular cartilage. Biomaterials $32: 1327-1338$.

48. Lienemann PS, Lutolf MP, Ehrbar M (2012) Biomimetic hydrogels for controlled biomolecule delivery to augment bone regeneration. Adv Drug Deliv Rev 64: 1078-1089.

49. Sundararaghavan HG, Masand SN, Shreiber DI (2011) Microfluidic generation of haptotactic gradients through $3 \mathrm{D}$ collagen gels for enhanced neurite growth. J Neurotrauma 28: 2377-2387.

50. Kothapalli CR, van Veen E, de Valence S, Chung S, Zervantonakis IK, et al. (2011) A high-throughput microfluidic assay to study neurite response to growth factor gradients. Lab Chip 11: 497-507.

51. Allazetta S, Hausherr TC, Lutolf MP (2013) Microfluidic synthesis of cell-type-specific artificial extracellular matrix hydrogels. Biomacromolecules 14: 1122-1131.

52. Zervantonakis IK, Hughes-Alford SK, Charest JL, Condeelis JS, Gertler FB, et al. (2012) Three-dimensional microfluidic model for tumor cell intravasation and endothelial barrier function. Proc Natl Acad Sci USA 109: 13515-13520.

53. Jang KJ, Mehr AP, Hamilton GA, McPartlin LA, Chung S, et al. (2013) Human kidney proximal tubule-on-a-chip for drug transport and nephrotoxicity assessment. Integr Biol (Camb) 5: 1119-1129.

54. Li CY, Stevens KR, Schwartz RE, Alejandro BS, Huang JH, et al. (2014). Micropatterned Cell-Cell Interactions Enable Functional Encapsulation of Primary Hepatocytes in Hydrogel Microtissues. Tissue Eng Part A 20: 22002212

55. Patel RG, Purwada A, Cerchietti L, Inghirami G, Melnick A, et al. (2014) Microscale Bioadhesive Hydrogel Arrays for Cell Engineering Applications. Cell Mol Bioeng 7: 394-408.

56. Gurski LA, Jha AK, Zhang C, Jia X, Farach-Carson MC (2009) Hyaluronic acid-based hydrogels as 3D matrices for in vitro evaluation of chemotherapeutic drugs using poorly adherent prostate cancer cells. Biomaterials 30 : 6076-6085.

57. Bal D, Ganguly S (2014) Enhancement of solute release from alginate scaffold with embedded sub-millimeter voids. J Biomater Sci Polym Ed 25: 51-60.

58. Tarameshlou M, Jafari SH, Rezaeian I, Khonakdar HA (2014) Synthesis of biocompatible and degradable microspheres based on 2-hydroxyethyl methacrylate via microfluidic method. J Appl Polym Sci 131: 40925.

59. Akbari S (2014) Microfluidic encapsulation of cells in alginate particles via an improved internal gelation approach. Microfluidics and Nanofluidics 16 : 773-777.

60. Ma H, Xu H, Qin J (2013) Biomimetic tumor microenvironment on a microfluidic platform. Biomicrofluidics 7: 11501.
61. Whisler JA, Chen MB, Kamm RD (2014) Control of Perfusable Microvascular Network Morphology Using a Multiculture Microfluidic System. Tissue Eng Part C Methods 20: 543-552.

62. Yu L, Chen MC, Cheung KC (2010) Droplet-based microfluidic system for multicellular tumor spheroid formation and anticancer drug testing. Lab Chip 10: $2424-2432$

63. Lee $\mathrm{KH}$, Lee $\mathrm{KH}$, Lee J, Choi $\mathrm{H}$, Lee $\mathrm{D}$, et al. (2014) Integration of microfluidic chip with biomimetic hydrogel for $3 D$ controlling and monitoring of cell alignment and migration. J Biomed Mater Res A 102: 1164-1172.

64. Shikanov A, Xu M, Woodruff TK, Shea LD (2011) A method for ovarian follicle encapsulation and culture in a proteolytically degradable 3 dimensional system. J Vis Exp.

65. Harink B, Le Gac S, Truckenmüller R, van Blitterswijk C, Habibovic P (2013) Regeneration-on-a-chip? The perspectives on use of microfluidics in regenerative medicine. Lab Chip 13: 3512-3528.

66. Sharma RI, Snedeker JG (2010) Biochemical and biomechanical gradients for directed bone marrow stromal cell differentiation toward tendon and bone. Biomaterials 31: 7695-7704

67. Guo F, French JB, Li P, Zhao H, Chan CY, et al. (2013) Probing cell-cell communication with microfluidic devices. Lab Chip 13: 3152-3162.

68. Torisawa YS, Mosadegh B, Luker GD, Morell M, O'Shea KS, et al. (2009) Microfluidic hydrodynamic cellular patterning for systematic formation of co-culture spheroids. Integr Biol (Camb) 1: 649-654.

69. Zervantonakis IK, Kothapalli CR, Chung S, Sudo R, Kamm RD (2011) Microfluidic devices for studying heterotypic cell-cell interactions and tissue specimen cultures under controlled microenvironments. Biomicrofluidics 5: 13406.

70. Hamilton SK, Bloodworth NC, Massad CS, Hammoudi TM, Suri S, et al (2013) Development of 3D hydrogel culture systems with on-demand cell separation. Biotechnol J 8: 485-495.

71. Sung JH, Esch MB, Prot JM, Long CJ, Smith A, et al. (2013) Microfabricated mammalian organ systems and their integration into models of whole animals and humans. Lab Chip 13: 1201-1212.

72. Huang CP, Lu J, Seon H, Lee AP, Flanagan LA, et al. (2009) Engineering microscale cellular niches for three-dimensional multicellular co-cultures. Lab Chip 9: 1740-1748.

73. Kobayashi A, Yamakoshi K, Yajima Y, Utoh R, Yamada M, et al. (2013) Preparation of stripe-patterned heterogeneous hydrogel sheets using microfluidic devices for high-density coculture of hepatocytes and fibroblasts. Journal of Bioscience and Bioengineering 116: 761-767.

74. Kitagawa Y, Naganuma Y, Yajima Y, Yamada M, Seki M (2014) Patterned hydrogel microfibers prepared using multilayered microfluidic devices for guiding network formation of neural cells. Biofabrication 6: 035011.

75. Geckil H, Xu F, Zhang X, Moon S, Demirci U (2010) Engineering hydrogels as extracellular matrix mimics. Nanomedicine (Lond) 5: 469-484.

76. Ranga A, Lutolf MP (2012) High-throughput approaches for the analysis of extrinsic regulators of stem cell fate. Curr Opin Cell Biol 24: 236-244.

77. Jeong GS, Han S, Shin Y, Kwon GH, Kamm RD, et al. (2011) Sprouting angiogenesis under a chemical gradient regulated by interactions with an endothelial monolayer in a microfluidic platform. Anal Chem 83: 8454-8459.

78. Kurth F, Eyer K, Franco-Obregón A, Dittrich PS (2012) A new mechanobiological era: microfluidic pathways to apply and sense forces at the cellular level. Curr Opin Chem Biol 16: 400-408.

79. Ingber DE (2006) Cellular mechanotransduction: putting all the pieces together again. FASEB J 20: 811-827.

80. Ando J, Yamamoto K (2013) Flow detection and calcium signalling in vascular endothelial cells. Cardiovasc Res 99: 260-268.

81. Kou S, Pan L, van Noort D, Meng G, Wu X, et al. (2011) A multishear microfluidic device for quantitative analysis of calcium dynamics in osteoblasts. Biochem Biophys Res Commun 408: 350-355. 
82. Lam RH, Sun Y, Chen W, Fu J (2012) Elastomeric microposts integrated into microfluidics for flow-mediated endothelial mechanotransduction analysis. Lab Chip 12: 1865-1873.

83. Gu L, Ordonez S, Black B, Mohanty SK (2013) Optofluidic control of axonal guidance. Proc. SPIE 8586, Optogenetics: Optical Methods for Cellular Control.

84. Govey PM, Jacobs JM, Tilton SC, Loiselle AE, Zhang Y, et al. (2014) Integrative transcriptomic and proteomic analysis of osteocytic cells exposed to fluid flow reveals novel mechano-sensitive signaling pathways. J Biomech 47:1838-1845

85. Ferrell N, Ricci KB, Groszek J, Marmerstein JT, Fissell WH (2012) Albumin handling by renal tubular epithelial cells in a microfluidic bioreactor. Biotechnol Bioeng 109: 797-803.

86. Kim YC, Kang JH, Park SJ, Yoon ES, Park JK (2007) Microfluidic biomechanical device for compressive cell stimulation and lysis. Sensors and Actuators B: Chemical 128: 108-116.

87. Huang Y, Nguyen NT, Lok KS, Lee PP, Su M, et al. (2013) Multiarray cell stretching platform for high-magnification real-time imaging. Nanomedicine (Lond) 8: 543-553.

88. Douville NJ, Zamankhan P, Tung YC, Li R, Vaughan BL, et al. (2011) Combination of fluid and solid mechanical stresses contribute to cell death and detachment in a microfluidic alveolar model. Lab Chip 11: 609-619.

89. Huang Y, Nguyen NT (2013) A polymeric cell stretching device for real-time imaging with optical microscopy. Biomed Microdevices 15: 1043-1054.

90. Tremblay D, Chagnon-Lessard S, Mirzaei M, Pelling AE, Godin M (2014) A microscale anisotropic biaxial cell stretching device for applications in mechanobiology. Biotechnol Lett 36: 657-665.

91. Zignego DL, Jutila AA, Gelbke MK, Gannon DM, June RK (2014) The mechanical microenvironment of high concentration agarose for applying deformation to primary chondrocytes. J Biomech 47: 2143-2148.

92. Raizman I, De Croos JN, Pilliar R, Kandel RA (2010) Calcium regulates cyclic compression-induced early changes in chondrocytes during in vitro cartilage tissue formation. Cell Calcium 48: 232-42.

93. Pingguan-Murphy B, Nawi I (2012) Upregulation of matrix synthesis in chondrocyte-seeded agarose following sustained bi-axial cyclic loading. Clinics (Sao Paulo) 67: 939-944.

94. Appelman TP, Mizrahi J, Seliktar D (2011) A finite element model of cell-matrix interactions to study the differential effect of scaffold composition on chondrogenic response to mechanical stimulation. J Biomech Eng 133 041010

95. Zhou J, Niklason LE (2012) Microfluidic artificial "vessels" for dynamic mechanical stimulation of mesenchymal stem cells. Integr Biol (Camb) 4: 1487 1497.

96. Xu T, Yue W, Li CW, Yao X, Yang M (2013) Microfluidics study of intracellular calcium response to mechanical stimulation on single suspension cells. Lab Chip 13: 1060-1069.

97. Magdesian MH, Sanchez FS, Lopez M, Thostrup P, Durisic N, et al. (2012) Atomic force microscopy reveals important differences in axonal resistance to injury. Biophys J 103: 405-414.

98. Jeon JE, Schrobback K, Meinert C, Sramek V, Hutmacher DW, et al. (2013) Effect of preculture and loading on expression of matrix molecules, matrix metalloproteinases, and cytokines by expanded osteoarthritic chondrocytes. Arthritis Rheum 65: 2356-67.

99. Verbruggen SW, Vaughan TJ, McNamara LM (2014) Fluid flow in the osteocyte mechanical environment: a fluid-structure interaction approach. Biomech Model Mechanobiol 13: 85-97.

100.Riehl BD, Lim JY (2012) Macro and microfluidic flows for skeletal regenerative medicine. Cells 1: 1225-1245.
101. Guillotin B, Guillemot F (2011) Cell patterning technologies for organotypic tissue fabrication. Trends Biotechnol 29: 183-190.

102. Kwon KW, Choi SS, Lee SH, Kim B, Lee SN, et al. (2007) Label-free, microfluidic separation and enrichment of human breast cancer cells by adhesion difference. Lab Chip 7: 1461-1468.

103. Lin YH, Yang YW, Chen YD, Wang SS, Chang YH, et al. (2012) The application of an Optically Switched Dielectrophoretic (ODEP) force for the manipulation and assembly of cell-encapsulating alginate microbeads in a microfluidic perfusion cell culture system for bottom up tissue engineering. Lab Chip 12: 1164-1173.

104. Allazetta S, Cosson S, Lutolf MP (2011) Programmable microfluidic patterning of protein gradients on hydrogels. Chem Commun (Camb) 47: 191-193.

105. Chung BG, Lee KH, Khademhosseini A, Lee SH (2012) Microfluidic fabrication of microengineered hydrogels and their application in tissue engineering. Lab Chip 12: 45-59.

106. Gurkan UA, Tasoglu S, Kavaz D, Demirel MC, Demirci U (2012) Emerging technologies for assembly of microscale hydrogels. Adv Healthc Mater 1: 149-158.

107. Wu W, DeConinck A, Lewis JA (2011) Omnidirectional printing of 3D microvascular networks. Adv Mater 23: 178-183.

108. Cosson S, Lutolf MP (2014) Hydrogel microfluidics for the patterning of pluripotent stem cells. Sci Rep 4: 4462.

109. Charwat V, Purtscher M, Tedde SF, Hayden O, Ertl P (2013) Standardization of microfluidic cell cultures using integrated organic photodiodes and electrode arrays. Lab Chip 13: 785-797.

110. Charwat V, Joksch M, Sticker D, Purtscher M, Rothbauer M, et al. (2014) Monitoring Cellular Stress Responses using Integrated High-Frequency Impedance Spectroscopy and Time-Resolved ELISA. Analyst 139: 5271-5282.

111. Jungreuthmayer C, Birnbaumer GM, Zanghellini J, Ertl P (2011) 3D numerical simulation of a lab-on-a-chip--increasing measurement sensitivity of interdigitated capacitors by passivation optimization. Lab Chip 11: 1318-1325.

112.Shoshi A, Schotter J, Schroeder P, Milnera M, Ertl P, et al. (2012) Magnetoresistive-based real-time cell phagocytosis monitoring. Biosens Bioelectron 36: $116-122$

113. Shoshi A, Schotter J, Schroeder P, Milnera M, Ertl P, et al. (2013) Contemporaneous cell spreading and phagocytosis: magneto-resistive real-time monitoring of membrane competing processes. Biosens Bioelectron 40: 82-88.

114. Ungerböck B, Charwat V, Ertl P, Mayr T (2013) Microfluidic oxygen imaging using integrated optical sensor layers and a color camera. Lab Chip 13: 1593-1601.

115. Nguyen DH, Stapleton SC, Yang MT, Cha SS, Choi CK, et al. (2013) Biomimetic model to reconstitute angiogenic sprouting morphogenesis in vitro. Proc Natl Acad Sci USA 110: 6712-6717.

116.Son KJ, Shin DS, Kwa T, Gao Y, Revzin A (2013) Micropatterned sensing hydrogels integrated with reconfigurable microfluidics for detecting protease release from cells. Anal Chem 85: 11893-11901.

117. Xu F, Moon SJ, Hefner E, Beyazoglu T, Emre AE, et al. (2010) A high-throughput label-free Cell Based Biosensor (CBB) system. Proceedings of SPIE--the International Society for Optical Engineering

118. Nguyen TA, Yin TI, Reyes D, Urban GA (2013) Microfluidic chip with integrated electrical cell-impedance sensing for monitoring single cancer cell migration in three-dimensional matrixes. Anal Chem 85: 11068-11076.

119. Valero T, Moschopoulou G, Kintzios S, Hauptmann P, Naumann M, et al. (2010) Studies on neuronal differentiation and signalling processes with a novel impedimetric biosensor. Biosens Bioelectron 26: 1407-1413.

120.Tran TB, Cho S, Min J (2013) Hydrogel-based diffusion chip with Electric Cell-substrate Impedance Sensing (ECIS) integration for cell viability assay and drug toxicity screening. Biosens Bioelectron 50: 453-459. 
121. Liu J (2011) Oligonucleotide-functionalized hydrogels as stimuli responsive materials and biosensors. Soft Matter 7: 6757-6767.

122.Xiong X, Wu C, Zhou C, Zhu G, Chen Z, et al. (2013) Responsive DNA-based hydrogels and their applications. Macromol Rapid Commun 34: 1271-1283.

123. Karathanasis SK (2014) Regenerative medicine: transforming the drug discovery and development paradigm. Cold Spring Harb Perspect Med.

124. Sung JH, Shuler ML (2012) Microtechnology for mimicking in vivo tissue environment. Ann Biomed Eng 40: 1289-1300.

125. Mahadik BP, Wheeler TD, Skertich LJ, Kenis PJ, Harley BA (2014) Microfluidic generation of gradient hydrogels to modulate hematopoietic stem cell culture environment. Advanced Healthcare Materials; 3: 449-458.

126. Sant S, Hancock MJ, Donnelly JP, lyer D, Khademhosseini A (2010) BIOMIMETIC GRADIENT HYDROGELS FOR TISSUE ENGINEERING. Can J Chem Eng 88: 899-911.

127.Eydelnant IA, Betty Li B, Wheeler AR (2014) Microgels on-demand. Nat Commun 5: 3355.

128. Yamada M, Utoh R, Ohashi K, Tatsumi K, Yamato M, et al. (2012) Controlled formation of heterotypic hepatic micro-organoids in anisotropic hydrogel microfibers for long-term preservation of liver-specific functions. Biomaterials 33: 8304-8315.

129. Wu J, Chen Q, Liu W, Zhang Y, Lin JM (2012) Cytotoxicity of quantum dots assay on a microfluidic 3D-culture device based on modeling diffusion process between blood vessels and tissues. Lab Chip 12: 3474-3480.

130.Bernard AB, Lin CC, Anseth KS (2012) A microwell cell culture platform for the aggregation of pancreatic $\beta$-cells. Tissue Eng Part $C$ Methods 18: 583 592.

131. Kunze A, Bertsch A, Giugliano M, Renaud P (2009) Microfluidic hydrogel layers with multiple gradients to stimulate and perfuse three-dimensional neuronal cell cultures. Procedia Chemistry 1: 369-372.

132. Kunze A, Meissner R, Brando S, Renaud P (2011) Co-pathological connected primary neurons in a microfluidic device for Alzheimer studies. Biotechnol Bioeng 108: 2241-2245.

133. Kunze A, Giugliano M, Valero A, Renaud $P$ (2011) Micropatterning neura cell cultures in 3D with a multi-layered scaffold. Biomaterials 32: 2088-2098.

134. Chen MB, Srigunapalan S, Wheeler AR, Simmons CA (2013) A 3D microfluidic platform incorporating methacrylated gelatin hydrogels to study physiological cardiovascular cell-cell interactions. Lab Chip 13: 2591-2598.

135. Verbridge SS, Chakrabarti A, DelNero P, Kwee B, Varner JD, et al. (2013) Physicochemical regulation of endothelial sprouting in a 3D microfluidic angiogenesis model. J Biomed Mater Res A 101: 2948-2956.

136. Jiang LY, Luo Y (2013) Guided assembly of endothelial cells on hydroge matrices patterned with microgrooves: a basic model for microvessel engineering. Soft Matter 9: 1113-1121.

137. Cuchiara MP, Gould DJ, McHale MK, Dickinson ME, West JL (2012) Integration of Self-Assembled Microvascular Networks with Microfabricated PEGBased Hydrogels. Adv Funct Mater 22: 4511-4518.

138. Morimoto Y, Tanaka R, Takeuchi S (2013) Construction of 3D, layered skin, microsized tissues by using cell beads for cellular function analysis. Adv Healthc Mater 2: 261-265.

139. Vincent LG, Choi YS, Alonso-Latorre B, del Álamo JC, Engler AJ (2013) Mesenchymal stem cell durotaxis depends on substrate stiffness gradient strength. Biotechnol J 8: 472-484.

140.Bischel LL, Young EW, Mader BR, Beebe DJ (2013) Tubeless microfluidic angiogenesis assay with three-dimensional endothelial-lined microvessels. Biomaterials 34: 1471-1477.

141. Chung S, Sudo R, Zervantonakis IK, Rimchala T, Kamm RD (2009) Surface-treatment induced three- dimensional capillary morphogenesis in a microfluidic platform. Adv Mater 21: 4863-4867.
142.Farahat WA, Wood LB, Zervantonakis IK, Schor A, Ong S, et al. (2012) Ensemble analysis of angiogenic growth in three-dimensional microfluidic cell cultures. PLoS One 7: 37333

143. Shin Y, Jeon JS, Han S, Jung GS, Shin S, et al. (2011) In vitro 3D collective sprouting angiogenesis under orchestrated ANG-1 and VEGF gradients. Lab Chip 11: 2175-2181.

144. Wong KH, Chan JM, Kamm RD, Tien J (2012) Microfluidic models of vascular functions. Annu Rev Biomed Eng 14: 205-230.

145. Hatherell K, Couraud PO, Romero IA, Weksler B, Pilkington GJ (2011) Development of a three-dimensional, all-human in vitro model of the blood-brain barrier using mono-, co-, and tri-cultivation Transwell models. J Neurosci Methods 199: 223-229.

146. Christman KL, Vardanian AJ, Fang Q, Sievers RE, Fok HH, et al. (2004) Injectable fibrin scaffold improves cell transplant survival, reduces infarct expansion, and induces neovasculature formation in ischemic myocardium. $J$ Am Coll Cardiol 44: 654-660.

147. Williams CG, Malik AN, Kim TK, Manson PN, Elisseeff JH (2005) Variable cytocompatibility of six cell lines with photoinitiators used for polymerizing hydrogels and cell encapsulation. Biomaterials 26: 1211-1218.

148. Kim SH, Lee JW, Choi I, Kim YC, Lee JB, et al. (2013) A microfluidic device with 3-d hydrogel villi scaffold to simulate intestinal absorption. J Nanosci Nanotechnol 13: 7220-7228.

149. Sung JH, Yu J, Luo D, Shuler ML, March JC (2011) Microscale 3-D hydroge scaffold for biomimetic Gastrointestinal (GI) tract model. Lab Chip 11: 389392.

150.van Midwoud PM, Verpoorte E, Groothuis GM (2011) Microfluidic devices for in vitro studies on liver drug metabolism and toxicity. Integr Biol (Camb) 3: $509-521$.

151. Goral VN, Yuen PK (2012) Microfluidic platforms for hepatocyte cell culture: new technologies and applications. Ann Biomed Eng 40: 1244-1254

152. Burkhardt B, Martinez-Sanchez JJ, Bachmann A, Ladurner R, Andreas K et al. ( 2014) Long-term culture of primary hepatocytes: new matrices and microfluidic devices. Hepatology International 8: 14-22.

153. Schütte J, Hagmeyer B, Holzner F, Kubon M, Werner S, et al. (2011) "Artificial micro organs"--a microfluidic device for dielectrophoretic assembly of liver sinusoids. Biomed Microdevices 13: 493-501.

154.Domansky K, Inman W, Serdy J, Dash A, Lim MH, et al. (2010) Perfused multiwell plate for 3D liver tissue engineering. Lab Chip 10: 51-58.

155.Baudoin R, Alberto G, Paullier P, Legallais C, Leclerc E (2012) Parallelized microfluidic biochips in multi-well plate applied to liver tissue engineering. Sensors and Actuators B: Chemical 173: 919-926.

156. Jang KJ, Cho HS, Kang do H, Bae WG, Kwon TH, et al. (2011) Fluid-shearstress-induced translocation of aquaporin-2 and reorganization of actin cytoskeleton in renal tubular epithelial cells. Integr Biol (Camb) 3: 134-141.

157. Kniazeva T, Hsiao JC, Charest JL, Borenstein JT (2011) A microfluidic respiratory assist device with high gas permeance for artificial lung applications. Biomed Microdevices 13: 315-323.

158. Choi J, Kim S, Jung J, Lim Y, Kang K, et al. (2011) Wnt5a-mediating neurogenesis of human adipose tissue-derived stem cells in a 3D microfluidic cell culture system. Biomaterials 32: 7013-7022.

159. Trkov S, Eng G, Di Liddo R, Parnigotto PP, Vunjak-Novakovic G (2010) Micropatterned three-dimensional hydrogel system to study human endothelial-mesenchymal stem cell interactions. J Tissue Eng Regen Med 4: 205-215.

160. Khoury M, Bransky A, Korin N, Konak LC, Enikolopov G, et al. (2010) A microfluidic traps system supporting prolonged culture of human embryonic stem cells aggregates. Biomedical Microdevices 12: 1001-1008.

161.Park JY, Kim SK, Woo DH, Lee EJ, Kim JH, et al. (2009) Differentiation of neural progenitor cells in a microfluidic chip-generated cytokine gradient. Stem Cells 27: 2646-2654. 
162. Moledina F (2011) A Microfluidic System for Mouse Embryonic Stem Cell Culture and Microenvironment Control. In Masters Abstracts International 50: 3 .

163. Wan CR, Chung S, Kamm RD (2011) Differentiation of embryonic stem cells into cardiomyocytes in a compliant microfluidic system. Ann Biomed Eng 39 1840-1847.

164. Kumachev A, Greener J, Tumarkin E, Eiser E, Zandstra PW, et al. (2011) High-throughput generation of hydrogel microbeads with varying elasticity for cell encapsulation. Biomaterials 32: 1477-1483.

165. Huh D, Hamilton GA, Ingber DE (2011) From 3D cell culture to organs-onchips. Trends Cell Biol 21: 745-754.

166. Hwang H, Park J, Shin C, Do Y, Cho YK (2013). Three dimensional multicellular co-cultures and anti-cancer drug assays in rapid prototyped multilevel microfluidic devices. Biomed Microdevices 15: 627-634.

167.Montanez-Sauri SI, Sung KE, Puccinelli JP, Pehlke C, Beebe DJ (2011) Automation of three-dimensional cell culture in arrayed microfluidic devices. $J$ Lab Autom 16: 171-185.

168. Hsiung LC, Chiang CL, Wang CH, Huang YH, Kuo CT, et al. (2011) Dielectrophoresis-based cellular microarray chip for anticancer drug screening in perfusion microenvironments. Lab Chip 11: 2333-2342.

169. Albanese A, Lam AK, Sykes EA, Rocheleau JV, Chan WC (2013) Tumouron-a-chip provides an optical window into nanoparticle tissue transport. Nat Commun 4: 2718

170.Wu MH, Chang YH, Liu YT, Chen YM, Wang SS, et al. (2011) Development of high throughput microfluidic cell culture chip for perfusion 3-dimensional cell culture based chemosensitivity assay. Sensors and Actuators, B: Chemical 155: 397-407.

171.Agastin S, Giang UB, Geng Y, Delouise LA, King MR (2011) Continuously perfused microbubble array for 3D tumor spheroid model. Biomicrofluidics 5: 24110 .

172.Pessi J, Santos HA, Miroshnyk I, Yliruusi J, Weitz DA, et al. (2014) Microfluidics-assisted engineering of polymeric microcapsules with high encapsulation efficiency for protein drug delivery. Int J Pharm 472: 82-87.

173. Jastrzebska E, Flis S, Rakowska A, Chudy M, Jastrzebski Z, et al. (2013) A microfluidic system to study the cytotoxic effect of drugs: the combined effect of celecoxib and 5-fluorouracil on normal and cancer cells. Mikrochim Acta 180: 895-901.

174. Imura Y, Yoshimura E, Sato K (2012) Micro total bioassay system for ora drugs: evaluation of gastrointestinal degradation, intestinal absorption, hepatic metabolism, and bioactivity. Anal Sci 28: 197-199.

175. Ramello C, Paullier P, Ould-Dris A, Monge M, Legallais C, et al. (2011) Investigation into modification of mass transfer kinetics by acrolein in a renal biochip. Toxicol In Vitro 25: 1123-1131.
176. Charwat V, Rothbauer M, Tedde SF, Hayden O, Bosch JJ, et al. (2013) Monitoring dynamic interactions of tumor cells with tissue and immune cells in a lab-on-a-chip. Anal Chem 85: 11471-11478.

177. Irimia D (2014) Cell migration in confined environments. Methods Cell Biol 121: $141-153$.

178. Shin Y, Han S, Jeon JS, Yamamoto K, Zervantonakis IK, et al. (2012) Microfluidic assay for simultaneous culture of multiple cell types on surfaces or within hydrogels. Nat Protoc 7: 1247-1259.

179. Hosmane S, Fournier A, Wright R, Rajbhandari L, Siddique R, et al. (2011) Valve-based microfluidic compression platform: single axon injury and regrowth. Lab Chip 11: 3888-3895.

180.Ertl P, Heer R (2009) Interdigitatedimpendance sensors for analysis of biological cells in microfluidic biochips. Elektrotechnik \& Informationstechnik 126: $47-50$.

181. Heinemann M, Zenobi R (2011) Single cell metabolomics. Curr Opin Biotechnol 22: 26-31.

182. Shintu L, Baudoin R, Navratil V, Prot JM, Pontoizeau C, et al. (2012) Metabolomics-on-a-chip and predictive systems toxicology in microfluidic bioartificial organs. Anal Chem 84: 1840-1848.

183. Takeda M, Shiku H, Ino K, Matsue T (2011) Electrochemical chip integrating scalable ring-ring electrode array to detect secreted alkaline phosphatase. Analyst 136: 4991-4996.

184. Kovarik ML, Gach PC, Ornoff DM, Wang Y, Balowski J, et al. (2012) Micro total analysis systems for cell biology and biochemical assays. Anal Chem 84: 516-54.

185. Mehta G, Hsiao AY, Ingram M, Luker GD, Takayama S (2012) Opportunities and challenges for use of tumor spheroids as models to test drug delivery and efficacy. J Control Release 164: 192-204.

186. Baker M (2011) Tissue models: a living system on a chip. Nature 471: $661-$ 665.

187.van der Meer AD, van den Berg A (2012) Organs-on-chips: breaking the in vitro impasse. Integr Biol (Camb) 4: 461-470.

188. Kilinc D, Peyrin JM, Soubeyre V, Magnifico S, Saias L, et al. (2011) Wallerian like degeneration of central neurons after synchronized and geometrically registered mass axotomy in a three-compartmental microfluidic chip. Neurotoxic Res 19: 149-161.

189. Felder M, Sallin P, Barbe L, Haenni B, Gazdhar A, et al. (2012) Microfluidic wound-healing assay to assess the regenerative effect of HGF on wounded alveolar epithelium. Lab Chip 12: 640-646.

190. Ertl P, Sticker D, Charwat V, Kasper C, Lepperdinger G (2014) Lab-on-a-chip technologies for stem cell analysis. Trends Biotechnol 32: 245-253. 